\title{
Regionalism and diffusion revisited: From final design towards stages of decision-making
}

\author{
FRANCESCO DUINA AND TOBIAS LENZ*
}

\begin{abstract}
An emerging research program on diffusion across regional international organizations (RIOs) proposes that decisions taken in one RIO affect decision-making in other RIOs. This work has provided a welcome corrective to endogenously-focused accounts of RIOs. Nevertheless, by focusing on the final design of policies and institutional arrangements, it has been conceptually overly narrow. This has led to a truncated understanding of diffusion's impact and to an unjustified view of convergence as its primary outcome. Drawing on public policy and sociological research, we offer a conceptual framework that seeks to remedy these weaknesses by disaggregating the decision-making process on the 'receiving' side. We suggest that policies and institutional arrangements in RIOs result from three decision-making stages: problematization (identification of something as a political problem), framing (categorization of the problem and possible solutions), and scripting (design of final solutions). Diffusion can affect any combination of these stages. Consequently, its effects are more varied and potentially extensive than is currently recognized, and convergence and persistent variation in scripting are both possible outcomes. We illustrate our framework by re-evaluating research on dispute settlement institutions in the EEC, NAFTA, and SADC. We conclude by discussing its theoretical implications and the conditions that likely promote diffusion.
\end{abstract}

Francesco Duina is Professor and Chair of Sociology at Bates College (USA) and Honorary Professor of Sociology at the University of British Columbia (Canada). His research focuses on comparative regional integration. His most recent articles have appeared in New Political Economy, Regulation \& Governance, and Comparative European Politics. He is the author of The Social Construction of Free Trade: The EU, NAFTA, and Mercosur (Princeton University Press) and other books on the institutional underpinnings of international economic life. During 2010-2015 he sat on the editorial board of the Journal of European Public Policy.

Tobias Lenz is a Max Weber Fellow at the European University Institute. He is currently on leave from the University of Goettingen, Germany, and the German Institute of Global and Area Studies (GIGA), Hamburg, where he is Assistant Professor (Juniorprofessor) of Global Governance and Comparative Regionalism. He holds a D.Phil in International Relations and an M.Phil in Politics, both from Oxford University. His research interests include international organizations, comparative regionalism, diffusion, EU external relations and IR theory. His current work focuses on processes of institutional change in regional organizations and the influence of the European Union on such processes.

\section{Introduction}

A growing literature on diffusion in political science, sociology, economics, and law argues that rules, organizational norms, and models developed in one political setting shape organizational decision-making in other settings. This theoretical perspective underpins an emerging research program on diffusion across regional international organizations (RIOs). Scholars suggest that RIOs are not atomistic entities whose emergence and evolution can be understood in isolation from other RIOs. Instead, 
underlying decision-making processes are interdependent because of material, social, and cultural connections between RIOs. ${ }^{1}$ Many of these new studies have shown convincingly that diffusion matters for understanding a wide range of empirical phenomena in RIOs. In so doing, they provide a welcome corrective to the tendency in the existing literature to view RIOs as driven solely by endogenous - functionalist, intergovernmental, cultural, and other - factors.

Nevertheless, this research program has yet to realize its full potential due to a major conceptual limitation. There is a widespread tendency to think of diffusion as affecting only the final design of policies or institutional arrangements in RIOs. This has resulted in a truncated understanding of the possible impact of diffusion across RIOs, and has promoted an unjustified view of convergence, understood as a tendency towards increasing similarity in final designs, as its primary outcome. ${ }^{2}$ This narrow focus in much of the literature is surprising for at least two reasons. First, it is widely recognized that organizational decision-making processes, which are conceptualized as interdependent in RIO diffusion studies, are not singular events but tend to consist of several phases or stages. ${ }^{3}$ Second, many studies recognize empirically that adaptation of foreign models is a frequent outcome of diffusion; full convergence is actually rather rare. 4

In this article, we respond to Etel Solingen's call to develop conceptual tools that 'enable adequate discrimination among different degrees of diffusion' by moving the conceptual focus towards the decision-making process in the receiving organizations. We draw on the public policy literature and organizational sociology research to identify three conceptually distinct and sequential decision-making stages and leverage them to understand the creation of RIO policies and institutions: problematization, that is, the

\footnotetext{
* The order of authors' names reflects alphabetical convention; both authors have contributed equally to all work. An earlier version of this article was presented at the International Studies Association Conference in Toronto, March 2014. We thank the participants at the meeting, as well as Julia Gray, Joe Jupille, three anonymous reviewers and the editors for their most useful comments. Tobias Lenz acknowledges support from the European Research Council Advanced Grant \#249543 'Causes and Consequences of Multilevel Governance', and a Daimler and Benz Foundation postdoctoral scholarship.

${ }^{1}$ Anja Jetschke and Tobias Lenz, 'Does Regionalism Diffuse? A New Research Agenda for the Study of Regional Organizations', Journal of European Public Policy, 20:4 (2013), pp. 626-37.

${ }^{2}$ See Jens Beckert, 'Institutional Isomorphism Revisited: Convergence and Divergence in Institutional Change', Sociological Theory, 28:2 (2010), pp. 150-66.

${ }^{3}$ See, for example, James Anderson, Public Policymaking (New York: Praeger, 1975).

${ }^{4}$ Amitav Acharya, 'How Ideas Spread: Whose Norms Matter? Norm Localization and Institutional Change in Asian Regionalism', International Organization, 58:2 (2004), pp. 239-75; Robyn Klingler-Vidra and Philip Schleifer, 'Convergence More or Less: Why Do Practices Vary as They Diffuse?', International Studies Review, 16:2 (2014), pp. 264-74; Tobias Lenz, 'EU Normative Power and Regionalism: Ideational Diffusion and Its Limits', Cooperation and Conflict, 48:2 (2013), pp. 211-28.
} 
identification of something as a political problem; framing, or the categorization of the problem and possible solutions; and scripting, that is, the design of final solutions. We contend that diffusion can affect any combination of these stages. It follows that its effects are more varied than currently acknowledged. Convergence in final design is just one possible outcome; diffusion might also matter when we observe persistent variation in final design.

We illustrate the usefulness of our framework in an empirical realm that has received much recent scholarly attention: the creation of dispute settlement institutions - that is, institutions endowed with the competence to adjudicate disputes and ensure the enforcement of legal commitments. We turn to three RIOs: the European Economic Community (EEC), NAFTA, and the Southern African Development Community (SADC). Our analysis suggests that diffusion influenced the framing stage in the European Court of Justice, and both the problematization and framing stages in NAFTA. In the case of SADC, diffusion affected all three stages - with the EU providing the scripts for the final stage, as already argued by Alter, Lenz and Osiemo. ${ }^{5}$ Convergence in outcome thus can only be seen in the SADC case (with its adoption of the EU model), but this does not mean that diffusion did not matter in the other cases. On the contrary, in those cases diffusion affected earlier stages of decision-making and helped set the context for persistent variation in design later on.

Our conceptual approach has three important broader theoretical implications. First, it suggests that diffusion, beyond being a force for convergence in final designs, is also a force for institutional or policy change more broadly. Especially if diffusion triggers the recognition of a situation as a problem that requires political action (problematization) and the way in which the problem is understood (framing), it provides a strong impetus for departing from the status quo. Diffusion accounts, then, challenge not only functional theories of institutional design and public policymaking, but also variants of neo-institutionalist theories that predict organizational stability. Second, our framework lends support to the view, rejected by most mainstream diffusion theorists, that diffusion can matter even in situations in which final designs (models) are considered for adoption but ultimately rejected. Third, our approach offers a new way of conceptualizing the relationship between diffusion and domestic politics in generating outcomes - two factors that are often seen as theoretical anti-theses, not

\footnotetext{
${ }^{5}$ Karen J. Alter, 'The Global Spread of European Style International Courts', West European Politics, 35:1 (2012), pp. 135-54; Karen J. Alter, The New Terrain of International Law: Courts, Politics, Rights (Princeton: Princeton University Press, 2013); Tobias Lenz, 'Spurred Emulation: The EU and Regional Integration in Mercosur and SADC', West European Politics, 35:1 (2012), pp. 155-74; Onsando Osiemo, 'Lost in Translation: The Role of African Regional Courts in Regional Integration in Africa', Legal Issues of Economic Integration, 41:1 (2014), pp. 87-122.
} 
least in the prominent localization debate. By replacing a narrow focus on ultimate outcomes with a disaggregated view of the decision-making process in the receiving organization, we come to appreciate that diffusion and domestic politics can interact in sequential fashion and, together, affect final outcomes in RIOs.

The article proceeds in four parts. We begin with a brief overview of existing research on diffusion among RIOs and outline its limitations. In Part II, we propose our conceptual framework. In Part III we illustrate it empirically through a structured comparison of the initial creation of dispute settlement institutions of the EEC, NAFTA, and SADC. Finally, we discuss the theoretical implications of our framework, and propose two general conditions that seem to promote diffusion in the three stages of decision-making.

\section{Diffusion studies of regional international organizations: Research program and limitations}

Diffusion denotes the process by which ideas, policies, institutions, and organizational activities developed in one context affect political choices in another context in the absence of centralized coordination or coercion. From this perspective, decision-making is interdependent, not independent, across political settings; actors factor in choices made elsewhere as they weigh their options. ${ }^{6}$ In general, diffusion scholars take issue with the widespread if often implicit assumption that decisions in one political setting can be adequately understood in atomistic terms as unfolding in isolation from developments in other settings. ${ }^{7}$

This theoretical perspective underpins an emerging research program on diffusion among RIOs. Until recently, scholars offered accounts of RIOs that focused almost exclusively on conditions and processes internal to the relevant region. Those accounts are now being challenged. International political economists argue, for example, that

6 Zachary Elkins and Beth Simmons, 'On Waves, Clusters, and Diffusion: A Conceptual Framework', Annals of the American Academy of Political and Social Science, 598 (2005), p. 35; see also Fabrizio Gilardi, 'Transnational Diffusion: Norms, Ideas and Policies', in Walter Carlsnaes, Thomas Risse, and Beth A. Simmons (eds), Handbook of International Relations (London: Sage, 2012), pp. 453-77. There is some disagreement in the literature over whether centralized coordination and coercion should form part of the definition of diffusion. We opt for a narrower definition of diffusion as a decentralized process to avoid using it as catch-all concept for almost any form of outside influence. This also allows us to disaggregate it more easily into separate stages that can be investigated with some precision.

7 See Detlef Jahn, 'Globalization as "Galton's Problem": The Missing Link in the Analysis of Diffusion Patterns in Welfare State Development', International Organization, 60:2 (2006), pp. 401-31. 
governments in one RIO craft trade agreements conditional upon the existence of similar agreements elsewhere. ${ }^{8}$ Recent research examining the language of regional trade agreements even shows that 'most PTAs [preferential trade agreements] take the overwhelming majority of their content verbatim from existing agreements.' ${ }^{9}$ There is a rapidly growing literature on the diffusion to other regions of models inspired by the EU for international courts, parliaments, and market integration agreements. 10 Constructivists suggest that security and democracy norms developed in Europe have travelled to regions across the global South. ${ }^{11}$ Policy analysts furthermore show that specific policies in some RIOs, such as those concerning the regulation of trade or labor rights, have served as templates for the creation of policies in other RIOs.12 Overall, these studies have accumulated wide-ranging evidence that the impact of diffusion is

${ }^{8}$ Leonardo Baccini and Andreas Dür, 'The New Regionalism and Policy Interdependence', British Journal of Political Science, 42:1 (2012), pp. 57-79; Joseph Jupille, Brandy Joliff, and Stefan Wojcik, 'Regionalism in the World Polity', Social Science Research Network (28 March 2013),

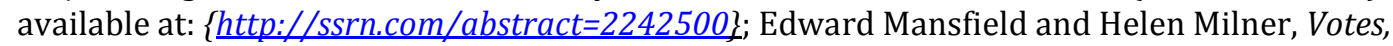
Vetoes, and the Political Economy of International Trade Agreements (Princeton: Princeton University Press, 2012); Walter Mattli, The Logic of Regional Integration: Europe and Beyond (Cambridge: Cambridge University Press, 1999).

${ }^{9}$ Todd Allee and Manfred Elsig, 'Are the Contents of International Treaties Copied-and-Pasted? Evidence from Preferential Trade Agreements', paper presented at the 8th Annual Conference on the Political Economy of International Organizations, February 12-14, Berlin, Germany (2015), p. 3, emphasis added.

10 Karen J. Alter, Laurence R. Helfer, and Osvaldo Saldías, 'Transplanting the European Court of Justice: The Experience of the Andean Tribunal of Justice', American Journal of Comparative Law, 60:3 (2012), pp. 629-64; Tanja Börzel and Thomas Risse, 'From Europeanization to Diffusion: Introduction', West European Politics, 35:1 (2012), pp. 1-19; Tanja Börzel and Vera van Hüllen (eds), Governance Transfer by Regional Organizations: Patching Together a Global Script (Basingstoke: Palgrave Macmillan, 2015); Anja Jetschke, 'Institutionalizing ASEAN: Celebrating Europe through Network Governance', Cambridge Review of International Affairs, 22:3 (2009), pp. 407-26; Clarissa F. Dri, 'Limits of the Institutional Mimesis of the European Union: The Case of the Mercosur Parliament', Latin American Policy, 1:1 (2010), pp. 52-74; Jürgen Rüland and Karsten Bechle, 'Defending State-Centric Regionalism through Mimicry and Localization: Regional Parliamentary Bodies in the Association of Southeast Asian Nations (ASEAN) and Mercosur', Journal of International Relations and Development, 17 (2014), 61-88.

${ }^{11}$ Acharya, 'How Ideas Spread'; Jean Grugel, 'Democratization and Ideational Diffusion: Europe, Mercosur and Social Citizenship', Journal of Common Market Studies, 45:1 (2007), pp. 43-68; Hiro Katsumata, 'Mimetic Adoption and Norm Diffusion: "Western" Security Cooperation in Southeast Asia?', Review of International Studies, 37:2 (2011), pp. 557-76; Jürgen Rüland, 'The Limits of Democratizing Interest Representation: ASEAN's Regional Corporatism and Normative Challenges', European Journal of International Relations, 20:1 (2014), pp. 237-61.

${ }^{12}$ Leonardo Baccini, Andreas Dür, and Yoram Haftel, 'Imitation and Innovation in International Governance: The Diffusion of Trade Agreement Design', in Andreas Dür and Manfred Elsig (eds), Trade Cooperation: The Purpose, Design and Effects of Preferential Trade Agreements (Cambridge: Cambridge University Press, 2014) pp. 167-94; Francesco Duina, 'Frames, Scripts, and the Making of Regional Trade Agreements', in Rawi Abdelal, Mark Blyth, and Craig Parsons (eds), Constructing the International Economy (Ithaca, NY: Cornell University Press, 2010), pp. 93-113; Anna van der Vleuten, Anouka van Eerdewijk, and Conny Roggeband (eds), Gender Equality Norms in Regional Governance (London: Palgrave Macmillan, 2014). For an excellent overview of this literature, see Thomas Risse, 'The Diffusion of Regionalism, Regional Institutions, and Regional Governance', in Tanja Börzel and Thomas Risse (eds), Oxford Handbook of Comparative Regionalism (Oxford: Oxford University Press, forthcoming). 
'certainly not spurious',13 and they suggest, more broadly, that our understanding of RIOs is incomplete unless we take processes of diffusion into account.

Yet this emerging research program still has to realize its full potential due to a major conceptual weakness. It focuses almost exclusively on how final designs of policies or institutional arrangements travel between RIOs. This has led not only to a truncated understanding of the potential influence of diffusion, but also to an unjustified view of convergence in final designs as the primary outcome of diffusion processes. Many diffusion studies take the adoption of a particular institutional form, such as a regional trade agreement or a regional parliamentary body, as their dependent variable. ${ }^{14}$ When adoption occurs, convergence in basic institutional features is the result. Yet even studies that move beyond a binary conceptualization of adoption display a similar tendency. Consider the following illustration.

In a recent study, Karen Alter demonstrated that the European Court of Justice (ECJ) has shaped the creation of dispute settlement institutions in other RIOs across the world. ${ }^{15}$ She documents the existence of eleven ECJ copies, indicating 'a revealed preference to emulate the ECJ'.16 Like their European model, these courts distinguish themselves from conventional international courts through their use of a supranational commission that monitors state compliance, a preliminary rulings mechanism, and a system of administrative and constitutional review that provides for private access. ${ }^{17}$ This is a striking finding given that the ECJ is "known for being activist and sovereignty compromising'18 - a result that we would expect governments in most other countries would prefer to avoid. It is also theoretically important because it challenges established functional theories of delegation to international dispute settlement institutions that depict them solely as rational responses to structural conditions internal to the respective organizations. ${ }^{19}$

While Alter convincingly shows that diffusion matters for understanding the final design of dispute settlement institutions in many RIOs, two crucial questions about diffusion's precise theoretical significance are difficult to answer on the basis of her analysis. First, does her account suggest that, in RIOs without a court modeled on the

\footnotetext{
13 Tanja Börzel and Thomas Risse, 'When Europeanisation Meets Diffusion: Exploring New Territory', West European Politics, 35:1 (2012), p. 194.

${ }^{14}$ Baccini and Dür, 'New Regionalism and Policy Interdependence'; Mattli, 'Logic of Regional Integration'; Jetschke, Anja and Murray, Philomena, 'Diffusing Regional Integration: The EU and Southeast Asia', West European Politics, 35:1 (2012), pp. 174-91.

${ }^{15}$ Alter, 'The Global Spread of European Style International Courts'.

${ }^{16}$ Alter, 'The Global Spread of European Style International Courts', p. 145.

17 See Alter, The New Terrain of International Law.

${ }^{18}$ Alter, The New Terrain of International Law, p. 90.

${ }^{19}$ For example, James McCall Smith, "The Politics of Dispute Settlement Design: Legalism in Regional Trade Pacts', International Organization, 54:1 (2000): 137-80.
} 
ECJ, diffusion from Europe did not matter at all? By focusing strictly on final design, Alter may have missed other types of diffusion effects. Second, is it justified to assume that convergence can be the only result of - and evidence for - diffusion? Should we not look for diffusion even when we observe continued variation in final designs? Put differently, did Alter miss other potentially relevant cases? Taken together, these questions suggest that the existing scholarship on RIOs at once may be underestimating the role of diffusion (to the extent that it operates at stages other than final design) and, when evidence in its favor is found when it comes to final designs, may be attributing to it too much importance (given that it is then generally seen as one, if not the major, explanatory variable) - as, indeed, a number of scholars have started to suspect. 20

An important next step, then, is to expand the research focus so as to include but go beyond final design. This requires, we believe, a more nuanced view of the decisionmaking process underlying the adoption of final designs. Below, we turn to the literature on public policy and organizational sociology to elaborate a coherent conceptual framework around this idea.

\section{Diffusion and stages of decision-making: A conceptual framework}

Our framework starts from a conceptualization of diffusion that has become widely accepted in contemporary research: it is best seen as a process, not an outcome, characterized by interdependent and decentralized decision-making across units of analysis, be they states or international organizations. ${ }^{21}$ Whereas recent work on diffusion has focused on dissecting the transfer process from one political setting to another with a focus on final designs, ${ }^{22}$ we propose to disaggregate the decision-making process in the receiving organization. We thus view the potential impact of diffusion as more extensive than is depicted in current research. Our specific focus is on diffusion across legally distinct RIOs, be they in different geographical areas or overlapping ones, and in place at the same point or different points in time.

We propose that organizational decision-making encompasses three analytically distinct and sequential stages. First, actors identify a problem as requiring political

\footnotetext{
${ }^{20}$ Acharya, 'How Ideas Spread', p. 241; Klingler-Vidra and Schleifer, 'Convergence More or Less', p. 264.

${ }^{21}$ Elkins and Simmons , 'On Waves, Clusters and Diffusion', pp. 35-36; Gilardi, 'Transnational Diffusion'.

${ }^{22}$ Solingen, 'Of Dominoes and Firewalls'; Etel Solingen and Tanja Börzel, 'Introduction to Presidential Issue: The Politics of International Diffusion - A Symposium', International Studies Review, 16:2 (2014), pp. 173-87.
} 
action - what we term problematization. Second, actors categorize this problem and the types of possible solutions - what we call framing. Third, actors generate specific policy and institutional solutions within the articulated frame - we refer to this as scripting (this is the step of typical interest in the existing scholarship with its focus on final design). ${ }^{23}$ Each of these stages follows distinct dynamics and is potentially influenced by different causal factors, providing the rationale for treating them as conceptually distinct. ${ }^{24}$ To be sure, as the case studies below also indicate, the boundaries between these stages are not always easy to draw in empirical analysis. Problematization and framing or framing and scripting sometimes go hand in hand, indicating that choices across the three stages may feed into one another. Problematizing an issue in a certain way tends to open up a certain universe of frames. Similarly, selecting certain frames over others renders the choice for certain scripts more likely. In short, decisions at an earlier stage may affect decisions at later ones - in line with the expectations of path dependence theorists. ${ }^{25}$ Our point, however, is precisely to propose, and then show empirically, that actors can in fact make de novo choices across these stages - and that diffusion can be a powerful force at each of them. Thus, whereas one model might serve as the basis for framing a decision, a different model might inspire scripting. Decisions at one stage do not fully determine decisions at later ones. At each stage, actors have considerable freedom over how, exactly, they respond to decisions taken at earlier stages.

Diffusion across RIOs, then, can affect any one of these decision-making stages independently and in any combination, including the possibility that it does not affect any of them at all (for example when policymakers in one RIO are unaware of, or simply ignore or reject, the problems, frames, and scripts adopted in other RIOs). Diffusion can thus not only affect scripting, as much recent diffusion research suggests, but also problematization and framing.

We depict our conceptual framework in Figure 1.

\footnotetext{
${ }^{23}$ This three-fold division is akin to the distinction between institutional change, institutional choice, and institutional design in recent works on institutions that use rational choice theory. See Joseph Jupille, Walter Mattli, and Duncan Snidal (eds), Instititional Choice and Global Commerce (Cambridge: Cambridge University Press, 2013); Barbara Koremenos, Charles Lipson, and Duncan Snidal, 'The Rational Design of International Institutions', International Organization, 54:4 (2001), pp. 761-99.

${ }^{24}$ John Kingdon, Agendas, Alternatives and Public Policy (Boston: Little, Brown and Co, 1984), p. 3; See also Herbert Simon, 'Political Research: The Decision-Making Framework', in David Easton (ed.), Varieties of Political Theory (Englewood Cliff: Prentice-Hall, 1966), pp. 15-24.

25 See, for instance, Paul Pierson, Politics in Time: History, Institutions, and Social Analysis (Princeton: Princeton University Press, 2004), chapter 1.
} 


\section{Policies and Institutional Arrangements}

$\uparrow$

\section{Decision-making}
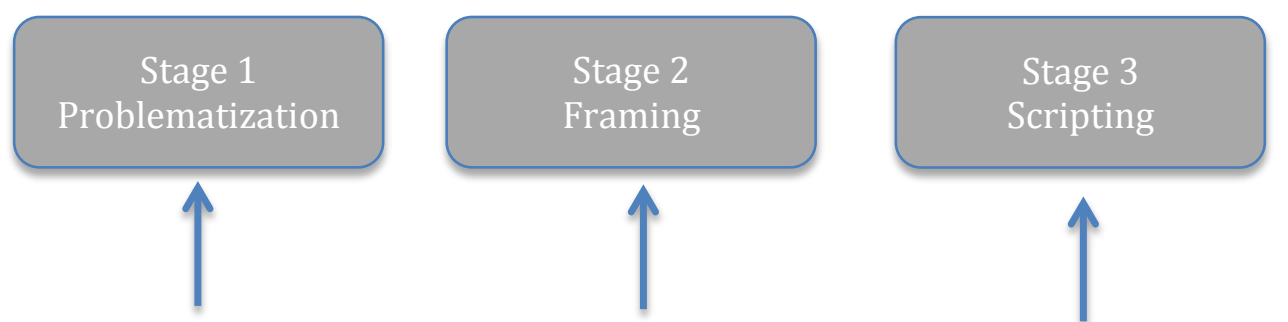

Diffusion
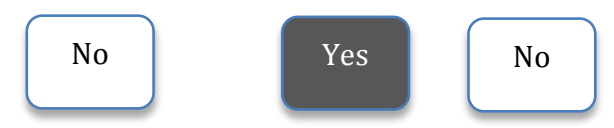

Yes

No

Figure 1. Diffusion and stages of decision-making.

Below, we explicate each of the three decision-making stages and how diffusion can operate in each. Empirical illustrations are drawn from work on RIOs and dispute settlement.

\section{Problematization}

Sociologists and other scholars of organizations have recognized for some time that 'problems' do not simply exist in the world but are in fact crafted through cognitive and societal processes. ${ }^{26}$ Departing from functionalist understandings of organizational structures and practices as reflecting 'objective' problems, they suggest that actors in organizations construct problems. As Kingdon notes, problems are 'not entirely selfevident. How people define something as a problem is worth some consideration.'27 Many 'objective' problems do not trigger political action because they are not perceived as problems, or because no solution is readily available. Indeed, the poor functioning of many regional economic organizations is a 'real' problem with surprisingly little political consequence. ${ }^{28}$ Many of these organizations persist as ill-functioning for years

\footnotetext{
${ }^{26}$ Michael D. Cohen, James G. March, and Johan P. Olsen, 'A Garbage Can Model of Organizational Choice', Administrative Science Quarterly, 17:1 (1972), pp. 1-25; Walter Powell and Paul DiMaggio (eds), The New Institutionalism in Organizational Analysis (Chicago: University of Chicago Press, 1991); Malcolm Spector and John I. Kitsuse, Constructing Social Problems (New Brunswick, NJ: Transaction Publishers, 2001).

27 Kingdon, Agendas, Alternatives and Public Policy, p. 95.

${ }^{28}$ See Julia Gray and Jonathan Slapin, 'How Effective Are Preferential Trade Agreements? Ask the Experts', Review of International Organizations, 7:3 (2012), pp. 309-33.
} 
and even decades without attempts to change the situation. From this perspective, problematization is the 'process by which given social conditions or arrangements come to be recognized as social problems' 29 , that is, problems that require political action. It is the first step toward the creation of new policies and institutional arrangements.

How does something become a problem? Scholars of organizations at times point to causal variables that are internal to an organization. Social constructivists posit that actors subscribe to particular normative viewpoints about the world that they use to problematize challenges, dysfunctions, strains, or sub-optimal outcomes that may emerge from within the organization. ${ }^{30}$ Moreover, the resources, expertise, and 'institutional logics' an organization is endowed with bias what types of occurrences are characterized as problems. ${ }^{31}$ Regarding dispute settlement, problematization might result from an endogenous learning process whereby actors become dissatisfied with current arrangements. For example, in Mercosur the 'reform of the DSS [dispute settlement system] was placed on the agenda as a result of perceived problems with the institutional status quo' due to defeats of the two larger member states Argentina and Brazil in dispute settlement. 32

The sources of problematization, however, can also be external to the organization. A crisis in a specific cultural and social context might spark problematization and thus organizational change. Policy-makers in Europe, for instance, 'viewed Hitler's extermination policy as exposing a limitation of international law' that required determined political action in a context in which a 'strong[...] norm supporting international and global judicial bodies' already existed..$^{33}$ The absence of a robust European human rights system thus became problematized, and ultimately led to the creation of the European Court of Human Rights in 1953. But, more pertinently for our purposes, scholars of policy learning and policy transfer have long recognized that

\footnotetext{
${ }^{29}$ Herbert Blumer, 'Social Problems as Collective Behavior', Social Problems, 18:3 (1971), p. 302, emphasis added.

${ }^{30}$ Darin Weinberg, 'On the Social Construction of Social Problems and Social Problems Theory: A Contribution to the Legacy of John Kitsuse', American Sociologist, 40:1/2 (2009), pp. 61-78; Michael Barnett and Martha Finnemore, Rules for the World: International Organizations in Global Politics (Ithaca: Cornell University Press, 2004).

31 William Ocasio, 'The Enactment of Economic Adversity: A Reconciliation of Theories of Failure-Induced Change and Threat-Rigidity', Research in Organizational Behavior, 17 (1995), pp. 287-331; William Ocasio, 'Toward an Attention-Based View of the Firm', Strategic Management Journal, 18:S1 (1997), pp. 187-206.

32 Christian Arnold and Berthold Rittberger, 'The Legalization of Dispute Resolution in Mercosur', Journal of Politics in Latin America, 5:3 (2013), p. 115.

33 Suzanne Katzenstein, 'In the Shadow of Crisis: The Creation of International Courts in the Twentieth Century', Harvard Journal of International Law, 55:1 (2014), pp. 188, 165.
} 
'problems' can travel between organizations. ${ }^{34}$ Similarly, students of organizations contend that organizations are embedded in organizational fields, and that interaction density, structure, and degree of consolidation generate pressures for institutional isomorphism. ${ }^{35}$

In this vein, we suggest that the recognition in one RIO of a problem as politically relevant can be the result of its construction in another RIO. Regional dispute settlement serves in this regard as a very pertinent example. During the 1960s and 1970s few regional integration projects entailed strong dispute settlement mechanisms because no link had been established between dispute settlement and the success of regional integration. As this changed due to the EU experience in the 1970s, the absence of supranational dispute settlement systems in other RIOs began to be seen as a problem. ${ }^{36}$ When policy-makers in the Association of Southeast Asian Nations, for example, started discussion on the removal of tariff and non-tariff barriers to trade in the early 1990s, experts quickly pointed to the EU and other RIO's experience in arguing that this undertaking is likely to fail in the absence of more solid institutions to ensure implementation ${ }^{37}$ - an argument that eventually convinced policy-makers. The problem of dispute settlement had diffused to ASEAN from the outside.

\section{Framing}

Once actors come to agree that a problem requires political action, they start thinking about ways of tackling it. As they do, they operate with certain 'frames' in mind. ${ }^{38}$ According to research on organizational action, social movements, and policy learning 39 ,

34 William E. Paterson and James Sloan, 'Learning from the West: Policy Transfer and Political Parties', Journal of Communist Studies \& Transition Politics, 21:1 (2005), pp. 33-47; Peter A. Hall, 'Policy Paradigms, Social Learning, and the State: The Case of Economic Policymaking in Britain', Comparative Politics, 25:3 (1993), pp. 275-96.

35 Paul DiMaggio and Walter Powell, "The Iron Cage Revisited: Institutional Isomorphism and Collective Rationality in Organizational Fields', American Sociological Review, 48:2 (1983), p. 148; John Meyer and Brian Rowan, 'Institutionalized Organizations: Formal Structure as Myth and Ceremony', American Journal of Sociology, 83:2 (1977), pp. 340-63.

36 Alter, Helfer and Saldías, 'Transplanting the European Court of Justice', pp. 629-32.

37 Jacques Pelkmans, 'Asean's Institutional Requirements with Special Reference to Afta',in Pearl Imada and Seiji Naya (eds), Afta: The Way Ahead (Singepore: Institute for Southeast Asian Studies, 1992), pp. 126-29; Rolf Langhammer, 'What Can Asean Learn from the Experience of European Integration? An EU Perspective', in Siow Yue Chia and Joseph Tan (eds), Asean \& EU: Forging New Linkages and Strategic Alliances (Singapore: Institute of Southeast Asian Studies, 1997), pp. 234-56.

38 Robert D. Benford and David A. Snow, 'Framing Processes and Social Movements: An Overview and Assessment', Annual Review of Sociology, 26 (2000), pp. 611-39.

${ }^{39}$ Ellen Reese and Garnett Newcombe, 'Income Rights, Mothers' Rights, or Workers' Rights? Collective Action Frames, Organizational Ideologies, and the American Welfare Rights Movement', Social Problems, 50:2 (2003), pp. 294-318; David Snow and Robert Benford, 'Master Frames and Cycles of Protest', in Aldon D. Morris and Carol McClurg Mueller (eds), Frontiers in Social Movement Theory (New Haven: Yale University Press, 1992), pp. 133-55. 
frames can be defined as 'collectively shared and accepted ways of interpreting situations and problems'.40 Frames include basic schemas, categories, causal pathways, and other cognitive tools. As such, frames are not the answers to the problem but, rather, the basic cognitive tools with which actors first categorize problems and then consider certain tools to solve them - what Barnett and Finnemore term 'classification.'41 By allowing actors to understand problems and to conceive of certain solutions, frames logically exclude alternative interpretations and solutions. We may say that they channel actors' cognitive abilities and efforts.

Categorization involves the assignment of labels to a perceived problem. A perceived violation of a supranational legal commitment, for instance, may be described as a 'failure of implementation' that has the potential to seriously undermine the credibility of regional integration more broadly. Such categorization allows actors to make sense of a problem - to give it essential traits and characteristics - and thus to render it amenable to certain kinds of solutions and not others. The identification of possible types of interventions therefore follows categorization. Certain problems, in other words, call for certain kinds of solutions and not others. ${ }^{42}$ To return to our example, by classifying a legal violation as an instance of implementation failure, policy-makers interpret it as part of a general and therefore potentially much larger problem that requires a solution appropriate to the problem at hand: an ad hoc remedial measure might not suffice, a systematic institutional solution is called for.

Where do frames come from? Social movement scholars note that frames are often available in society, as part of the proximate cultural environment in which actors operate. 43 Actors appropriate frames from their environment and use them to look at the problem at hand. The proposed solutions resonate with those actors and those around them. It would make little sense if matters were otherwise: frames that do not fit a particular cultural context have little chance of guiding actors towards solutions that will be appreciated and understood because they contain 'cultural repertoires' that make action intelligible. ${ }^{44}$ These insights are relevant for RIOs. Actors in those

\footnotetext{
40 Duina, 'Frames, Scripts, and the Making of Regional Trade Agreements', p. 100.

${ }^{41}$ Barnett and Finnemore, Rules for the World, pp. 31-32.

42 Jackie Smith, 'Bridging Global Divides?', International Sociology, 17:4 (2002), pp. 505-28.

${ }^{43}$ John Boli and George M. Thomas, 'Introduction', in John Boli and George M. Thomas (eds), Constructing World Culture: International Nongovernmental Organizations since 1875 (Stanford: Stanford University Press, 1999), p. 4; Sidney Tarrow, 'Mentalities, Political Cultures, and Collective Action Frames: Constructing Meanings through Action', in Aldon D. Morris and Carol McClurg Mueller (eds), Frontiers in Social Movement Theory (New Haven: Yale University Press, 1992), pp. 174-202.

${ }^{44}$ Mayer Zald, 'Culture, Ideology, and Strategic Framing', in Dough McAdam, John MacCarthy and Mayer Zald (eds.), Comparative Perspectives on Social Movements (Cambridge: Cambridge University Press, 1996), pp. 261-74.
} 
organizations operate in national or international cultural contexts rich with frames. For example, domestic legal systems contain manifold taken-for-granted assumptions about the nature of legal problems and adequate solutions that are likely to shape international negotiators' preferences. In this vein, Duina demonstrates a striking correspondence between the legal traditions of member states - common law vs. civil law - and the nature of dispute settlement mechanisms in regional trade agreements. ${ }^{45}$

However, we propose that frames can also come from other RIOs; frames diffuse between organizations. This can happen in multiple ways. For one, actors in one setting are inevitably bound to search for proven and appropriate frames by looking at what other RIOs are doing. They actively consult and examine those organizations. A second way is through more passive exposure: some frame used by one or more RIO may have acquired broad recognition already. A third path of diffusion is the active promotion (through training programs, published materials, conferences, etc.) on the part of one RIO of its frames for adoption by others. Such promotion can be further supported by backing from external actors such as politicians and experts in epistemic communities.

It follows that the RIO that serves as the 'provider' of frames need not have been involved in problematization; the two decision-making stages can be treated as independent. For instance, internal dynamics or exogenous crises may be responsible for problematization; once in place, the problem requires attention and organizational actors may then start looking beyond their confines for inspiration or, in a more passive fashion, may have already internalized dominant frames in their organizational fields. According to Alter et al., the idea of separate decision-making stages captures the process of the creation of the Andean Tribunal of Justice. Problematization had internal roots, with the practice of enacting secondary legislation by presidential decree without parliamentary approval leading policy-makers to view the Andean legal system as requiring political reform. Yet, framing was significantly affected by diffusion. Once policy-makers began to search for potential solutions, the problem was framed in terms of a lack of a supranational judicial review mechanism that could '[provide] a designated judicial body for challenging Andean law', a categorization that, in turn, inadvertently led policy-makers to view the 'the necessity to create a court' for the region. ${ }^{46}$ This frame had diffused from Europe to legal experts in the region via socialization and emulation processes. While the 'question of what type of court [to establish] remained

\footnotetext{
45 Francesco Duina, 'Making Sense of the Legal and Judicial Architectures of Regional Trade Agreements Worldwide', Regulation and Governance, doi: 10.1111/rego.12081.

46 Alter, Helfer and Saldias, 'Transplanting the European Court of Justice', p. 643.
} 
open'47, i.e. scripting had yet to be decided, the specific framing of the problem as requiring further supranational legal integration excluded alternative interpretations and other potential solutions, such as changing domestic constitutional provisions or involving national parliaments in the adoption of Andean secondary legislation.

\section{Scripting}

Once actors have categorized the problem and thereby pre-figured potential solutions, they set out to devise new policies and institutional arrangements. This final stage requires detailing the specific features that create an institution or policy. For example, how should a dispute settlement institution be composed? What specific competences should it have? And should its decisions be binding on member states? Following the terminology of world polity theory, we refer to this stage as the production of scripts, or scripting. ${ }^{48}$ RIO actors utilize scripts, or existing models, as building blocks for the final design of a new policy or institution. Sometimes, single scripts serve as ready-made templates for the design of policies and institutions; at other times, policies and institutions are patched together from different scripts. ${ }^{49}$ For example, the Mercosur dispute settlement mechanism combines elements from the World Trade Organization as well as from the European Court of Justice. ${ }^{50}$ And as we elaborate further below, even when specific templates are adopted, they are usually adapted to local conditions. As already noted, this is the stage of the decision making process upon which scholars of diffusion across RIOs have thus far focused almost exclusively.

The key question for us concerns the origins of those scripts. How do RIO actors produce them? Research suggests that RIO actors refer to the broader environment for inspiration. National governments, with their legal systems and extensive administrative structures, are significant producers and depositories of scripts on a large variety of topics. ${ }^{51}$ These are accessible and, depending on the issues on hand, RIO policymakers certainly consult them for insights. Much of the same can be said of the policy platforms on national political parties. Some domestic pressure groups make it their mission to provide ready-made policies for international organizations to adopt. They promote their work by publishing them on their websites or other media venues.

\footnotetext{
47 Ibid., p. 643.

48 Duina, 'Frames, Scripts, and the Making of Regional Trade Agreements', p. 100.

${ }^{49}$ Börzel and van Hüllen (eds), Governance Transfer by Regional Organizations.

50 Lenz, 'Spurred Emulation', p. 168; Arnold and Rittberger, 'The Legalization of Dispute Resolution in Mercosur', p. 122.

${ }^{51}$ David John Frank, Ann Hironaka, and Evan Schofer, 'The Nation-State and the Natural Environment over the Twentieth Century', American Sociological Review, 65:1 (2000), pp. 96116.
} 
As we demonstrate in the European case below, many of the design features of the European Court of Justice had their origin in German and Italian models.

At the same time, according to sociologists, international organizations themselves are also very important sources of scripts. ${ }^{52}$ These include transnational corporations, international industry-oriented bodies (such as the International Standards Organization, International Accounting Standards Committee, and World Health Organization), international development-oriented organizations (the OECD or World Bank, for example), and international lobbying and interest groups. ${ }^{53}$ The scripts originating from one international organization are easily accessible by actors in other international organizations. In many cases, they are actively promoted to those actors. 54 Consider, as an example, the IMF's recommended minimum deposit rules for personal accounts with international banks.

Along with existing scholarship on final design in RIOs, we posit that RIOs are important sources of scripts. Scripts diffuse, in other words, across legally distinct RIOs. The mechanisms of diffusion are once again varied. Officials in one RIO can turn to another RIO for inspiration. They may as well come under pressure (internally and externally) to adopt scripts that have proven successful in another RIO. The originating RIO may, for instance, offer financial compensation for adoption, or require it as a condition for something else to happen (a trade agreement between the two blocs, for instance). Powerful groups (consumer organizations, special interest associations, etc.) may also pressure officials in one RIO to follow the examples set by an official in another RIO. Expediency may of course also play a role: ready-made solutions are attractive in their own right. Karen Alter, in the piece discussed above, demonstrates that the European Court of Justice script has been widely adopted, sometimes with modifications, across RIOs in the global South.

Importantly, we should note that such diffusion of scripts can happen independently from that of frames or problems. As with frames, scripts may or may not come from the same sources that provided the problematization of something. They may also not come from the source of the relevant frames being utilized. Indeed, because they are rather concrete and explicitly articulated, scripts can be easily 'found' anywhere in world society and borrowed, irrespective of the prior work that has been done on a problem. Thus it is important to keep in mind that RIOs are only one of the many types of sources

\footnotetext{
52 Boli and Thomas, 'Introduction', pp. 1-10.

53 Francesco Duina and Peter Nedergaard, 'Learning in International Governmental Organizations: The Case of Social Protection', Global Social Policy, 10:2 (2010), pp. 193-217.

${ }^{54}$ Martha Finnemore, 'International Organizations as Teachers of Norms: The United Nations Educational, Scientific, and Cultural Organization and Science Policy', International Organization, 47:4 (1993), pp. 565-97.
} 
for scripts. The World Trade Organization and its predecessor, the General Agreement on Tariffs and Trade, have for instance served as influential sources of scripts for dispute settlement design in RIOs.

\section{Diffusion and Persistent Variation}

As already noted, much of the existing literature shares an implicit understanding of diffusion as the transfer of models across RIOs, even if they are synthesized in creative ways. As a result, scholarship to date has inextricably linked diffusion with convergence, or even homogenization, understood as a tendency of 'receiving' RIOs to become more similar to, or even alike, 'sending' RIOs in final designs. ${ }^{55}$ Yet, if diffusion affects only problematization and/or framing while innovation occurs in scripting, scriptural convergence does not take place; sending and receiving RIOs continue to display variation in this respect. Given the existing literature's focus on final designs, we refer to convergence only if diffusion affects the scripting stage, whereas we speak of persistent variation between sending and receiving RIO when diffusion effects are confined to problematization and/or framing. Our main argument is, therefore, that diffusion may be happening even when we observe persistent variation. As mentioned before, while scholars do recognize this empirically, we provide a coherent framework to ground these observations conceptually. We now have a more nuanced conceptual perspective on how diffusion can operate across RIOs, which allows us to improve upon the tendency to equate diffusion with convergence in final designs.

\section{Illustrations: Dispute settlement institutions in RIOs}

In this section, we illustrate our conceptual framework with a structured comparison of the creation of regional dispute settlement institutions in three RIOs: the EEC, NAFTA, and SADC. Based on existing secondary literature and our own research, we re-examine the decision-making episodes that led to the initial creation of such a body in the respective organizations with a view to discerning the role of diffusion at each stage. ${ }^{56}$

\footnotetext{
55 This is not to deny that some scholars, especially those interested in localization processes, tend to frame their inquiries into diffusion in terms of translation and adaptation rather than convergence. This rhetorical move notwithstanding, these scholars are hard-pressed to deny that if diffusion takes place, even when transferred models are extensively adjusted to fit local conditions, this increases similarity between the respective units in final designs when compared to the status quo antes, and therefore can be labeled a form of convergence.

${ }^{56}$ Some of these bodies changed subsequently. SADC, for example, later created a second dispute settlement mechanism in the context of the SADC Trade Protocol, and it disbanded the SADC
} 
We are interested in diffusion between RIOs, understood as transfers between distinct legal entities established by formal contracts between neighbouring countries.

We selected these case studies for several reasons. First, we wanted to illustrate the two central conceptual points in our argument: diffusion can generate a variety of effects along the decision-making process, operating not only at the final design (scripting) but also at the problematization and framing stages; and diffusion might play a role in decision-making even if convergence in final designs is not the outcome, which means that persistent variation is another potential outcome of diffusion processes. The three RIOs offer compelling evidence on these points. Second, the three case studies reflect distinct periods in the evolution of the international judiciary - the EEC in the post-World War Two era, NAFTA during the transition period at the end of the Cold War, and SADC in the post-Cold War era. This highlights the broad applicability of our framework.

Third, two of our case studies (the EEC and NAFTA) illustrate especially well how persistent variation can result even in circumstances where there would be strong reasons to expect diffusion in all three stages. As we shall see, there was within each region (Western Europe and North American) a preexisting - though legally distinct RIO which could have served as a convenient basis for the design of dispute resolution mechanisms. As path dependence and simple logic would lead us to expect, there certainly was some diffusion from those earlier RIOs - a high degree of co-membership, in our view, is certainly a condition conducive to diffusion, an issue we will come back to in the conclusion. But the fact that diffusion did not happen in all stages, and variation in final designs occurred in these two RIOs, is remarkable and instructive.

Our focus is on RIO-to-RIO diffusion. This means we do not examine in detail other sources of diffusion such as global organizations as well as potential second- or thirdorder diffusion effects that are 'the product of sedimentation of prior and historically more remote diffusion. ${ }^{57}$ We of course acknowledge those sources as important. The fact that dispute settlement mechanisms have become very common in international organizations ${ }^{58}$ has certainly influenced policymakers in many RIOs. We recognize this but then aim to trace, to the best possible extent, diffusion across RIOs.

Tribunal in 2012 following a controversial ruling against the Zimbabwian government. For an extended discussion of the latter, see Karen Alter, James Thuo Gathii, and Laurence Helfer, 'Backlash Against International Courts in West, East and South Africa: Causes and Consequences', iCourts Working Paper Series, No. 21 (2015).

57 Solingen, 'Of Dominoes and Firewalls', p. 633.

${ }^{58}$ Barbara Koremenos and Timm Betz, 'The Design of Dispute Settlement Procedures in International Agreements', in Jeffrey A. Dunnoff and Mark A. Pollack (eds), International Law 
Our findings, in brief, are these. In all three instances diffusion mattered. Yet, it did so very differently in each case. Existing research argues that the scripts that define SADC's dispute settlement institutions came from the EU. ${ }^{59}$ We concur with this view: the permanent and centralized dispute adjudication of the EU indeed found its way into SADC. Scholars have instead considered NAFTA (with its non-permanent and decentralized mechanism) and the EU itself as innovators: they built new mechanisms. As such, scholars have shown little interest in diffusion as a possible causal factor. In fact, we suggest that diffusion influenced the framing of potential solutions in the case of the European Court of Justice, and that it affected both the problematization and framing of dispute settlement in NAFTA. Indeed, in both cases, the 'originating' RIOs were in those two very regions respectively - but have been overlooked because of the assumption that lack of convergence means lack of diffusion. When it comes to SADC, moreover, diffusion certainly influenced scripts but also the steps of problematization and framing - something that has until now been overlooked. We summarize our discussion in Table 1.

\begin{tabular}{|c|c|c|c|}
\hline & $E U$ & NAFTA & $S A D C$ \\
\hline $\begin{array}{l}\text { Institutional } \\
\text { arrangement }\end{array}$ & $\begin{array}{l}\text { European Court of } \\
\text { Justice (1958): } \\
\text { permanent, } \\
\text { centralized dispute } \\
\text { adjudication }\end{array}$ & $\begin{array}{l}\text { Dispute settlement } \\
\text { mechanism for } \\
\text { investments } \\
\text { (1994): non- } \\
\text { permanent, } \\
\text { decentralized } \\
\text { dispute } \\
\text { adjudication } \\
\end{array}$ & $\begin{array}{c}\text { SADC Tribunal } \\
\text { (2000): permanent } \\
\text { centralized dispute } \\
\text { adjudication }\end{array}$ \\
\hline \multicolumn{4}{|l|}{$\begin{array}{l}\text { Influence of RIO } \\
\text { diffusion on: }\end{array}$} \\
\hline Problematization & No & Yes & Yes \\
\hline Framing & Yes & Yes & Yes \\
\hline Scripts & No & No & Yes \\
\hline $\begin{array}{l}\text { Institutional design } \\
\text { outcome }\end{array}$ & Persistent variation & Persistent variation & Convergence \\
\hline
\end{tabular}

Table 1: Diffusion and decision-making stages in three RIOs

Thus, diffusion mattered in all three cases, even when final institutional design varied. Importantly, diffusion was partial precisely in the two case studies - EEC and NAFTA -

and International Relations: Synthesizing Insights from Interdisciplinary Scholarship (Cambridge University Press, 2013).

${ }^{59}$ Alter, 'The Global Spread of European Style International Courts'; Alter, The New Terrain of International Law; Tobias Lenz, 'Spurred Emulation'; Osiemo, 'Lost in Translation'. 
where we would have expected it to be wholesale (since these two RIOs were created in areas where earlier, though legally distinct, RIOs were in place).

\section{European Economic Community}

The EEC, and later the European Union, is typically considered the source of diffusion for other RIOs and rarely the receiver. This is especially so in the case of its European Court of Justice, which was created in 1958 with the two Treaties of Rome - the EEC and the European Atomic Energy Community. Without question, the European Court of Justice has influenced the creation of courts in numerous RIOs. What is often not considered, however, is whether other RIO courts have shaped the European Court of Justice itself. A close examination of the historical record shows that diffusion happened at one juncture in particular: framing. The source was an RIO in Europe itself: the European Coal and Steel Community and its Court of Justice (the ECSC-CJ). Indeed, the ECSC-CJ, and not the European Court of Justice, should be considered perhaps the first and most original of the modern RIO courts.

A few clarifications about the ECSC-CJ are in order. It was not part of the original plans for the Treaty of Paris of 1951 which established the European Coal and Steel Community.60 It emerged as a possibility after the member states became concerned with questions of legal remedies and of the balancing the powers of the supranational European Coal and Steel Community High Authority with the interests of national governments. A committee of jurists was given the mandate to make proposals. France opposed any permanent court, but the Benelux countries and Germany favored it albeit for different reasons. ${ }^{61}$ Once the decision was made to have a court, intense negotiations ensued. The evidence points to inspiration coming from 'traditionalcontinental European types of administrative courts,'62 and, in particular, France's Conseil d'Etat, though its design ultimately 'defied easy categorisation'.63 The ESCS-CJ was accordingly designed without other RIO courts in mind, though it belonged to a post-War period during which new transnational courts of justices were being created (for instance, the Nuremberg Court and the European Court of Human Rights).

These developments influenced the European Court of Justice. In the early 1950s, the six European Coal and Steel Community members began contemplating integration

\footnotetext{
${ }^{60}$ Hjalte Rasmussen, On Law and Policy in the European Court of Justice: A Comparative Study in the European Court of Justice (Dordecht: Martinus Nijhoff Publishers, 1986), p. 207.

${ }^{61}$ Anne Boerger-De Smet, 'Negotiating the Foundations of European Law, 1950-57: The Legal History of the Treaties of Paris and Rome', Contemporary European History, 21:3 (2012), pp. 342-43.

62 Rasmussen, On Law and Policy in the European Court of Justice, p. 208.

63 Boerger-De Smet, 'Negotiating the Foundations of European Law', p. 346.
} 
efforts for their national economies and the production of atomic energy. While negotiating the treaties for the EEC and the European Atomic Energy Community (two new and legally distinct RIOs), 'it was by no means clear how the institutional structure of the two communities would look and whether it would include a Court'.64 Indeed, uncertainties about the need for a court featured in parallel discussions by federalists, such as the European Movement led by Paul Henri Spaak and other Europeans exploring a variety of futures for a united Europe (including a European Political Community, which could have had a need for a court). ${ }^{65}$

A new problem thus presented itself: did the process of adding two new RIOs in Europe necessitate the creation of new and shared supranational institutions? A fundamental disagreement was at the root of the question. In a sort of turnaround from its position during the European Coal and Steel Community creation, the French delegation to the Venice negotiations in May of 1956 made it clear it 'could not support a connection between the ECSC court and the two projected Communities'.66 France was opposed to a strong supranational judiciary capable of acting independently of national interests. But the other member states thought that the creation of the European Economic Community and the European Atomic Energy Community called for an integrated legal system (inclusive of the European Coal and Steel Community) and shared institutions, including a court. The challenge of building three parallel RIOs thus served as grounds for the problematization of the need for a possible court. In the language of this article, the first step of the process was therefore an internal matter: it had to do with the institutional logic of creating three RIOs.

There followed considerable debate over how best to proceed. Negotiators began categorizing the problem they faced and identifying a set of possible solutions - they began framing the issues on hand. The available evidence suggests that at this moment the ECSC-CJ became an important reference point (much as it had in the earlier discussions surrounding the European Political Community). ${ }^{67}$ Officials from all the member states but France reasoned that the EEC by virtue of its extensive legal framework would inevitably face a judicial problem similar to the one experienced by the European Coal and Steel Community, and that accordingly an independent permanent court analogous in general terms to the ECSC-CJ would be the appropriate

\footnotetext{
${ }^{64}$ Hjalte Rasmussen, "The Origins of a Legal Revolution: The Early History of the European Court of Justice', Journal of European Integration History, 14:2 (2008), p. 86.

65 Ibid, p. 80.

66 Ibid.

67 Ibid.
} 
type of solution ${ }^{68}$. Equally important, given that the European Coal and Steel Community would constitute one of the three RIOs in question, the judicial question would also involve the ECSC and, for the sake of institutional unity and coherence, should be dealt with by a single judicial body. The problem was therefore deemed to be judicial in nature, and the solution would also be the same. Thus, a network of pro-European jurists, including ESCS-ECJ General Advocate Maurice Lagrange, argued that '[ESCS-]ECJ jurisprudence laid the foundations for a genuinely European legal order on which a future Federal Court could base itself ${ }^{6}$. But the French government (along with some prominent politicians from other countries, such as the German Ministry of Economics) disagreed, and proposed that the solution be more 'technical' in nature: a Court of Arbitrage made up of a secretariat and ad hoc technical experts could suffice, given that only a few disputes would arise. ${ }^{70}$ The ECSC-CJ, for the French, was not an appropriate reference. The lack of consensus around solutions meant that the court was eventually removed from the agenda in late 1956, only to reappear at later rounds in the negotiations. $^{71}$

After securing important economic concessions, the French relented and the idea of a permanent court of justice was accepted..$^{72}$ The time had thus come to define its design - the script phase began. Here, if the ECSC-CJ was inspirational in the framing phase, it played a significantly lesser role in this third step. Now officials had to deal with three RIOs and the objectives and aspirations in question had considerably expanded..$^{73} \mathrm{~A}$ more powerful court, effectively dealing with constitutional tasks - i.e., with the ability 'to invalidate statutes and other acts of public authority found to be in conflict with a constitution'74 - was envisioned, and officials had to reach for new ideas and tools. As a group, key historical accounts, such as Boerger-De Smet's, ${ }^{75}$ depict the jurists charged with defining the court as operating with considerable freedom and independence and turned, at least for some inspiration, the national models (the Italian and German especially). ${ }^{76}$ The most important innovation was endowing the new European Court of Justice with the power to hear preliminary references from national courts concerning

\footnotetext{
68 Boerger-De Smet, 'Negotiating the Foundations of European Law', p. 349.

${ }^{69}$ Hjalte Rasmussen, 'The Origins of a Legal Revolution', p. 82.

70 Ibid, p. 87.

${ }^{71}$ Boerger-De Smet, 'Negotiating the Foundations of European Law', p. 349.

72 Ibid.

${ }^{73}$ Ditlev Tamm, 'The History of the Court of Justice of the European Union since its Origin', in Allan Rosas, Egils Levits, and Yves Bot (eds), The Court of Justice and the Construction of Europe: Analyses and Perspectives on Sixty Years of Case-Law (The Hague: TMC Asser Press, 2013), p. 16.

${ }^{74}$ Alec Stone Sweet, 'The European Court of Justice', in Paul Craig and Grainne De Burca (eds), The Evolution of EU Law (Oxford: Oxford University Press, 2011), p. 122.

75 Boerger-De Smet, 'Negotiating the Foundations of European Law', p. 351.

76 Ibid.
} 
the validity of domestic law and, with that, the unprecedented ability to interpret European law and issue preliminary rulings. ${ }^{77}$ This could in principle ensure uniform understanding throughout the Community 78 and would eventually have major implications for the activities of the court. The European Court of Justice was also given powers to review the legality of acts by the Council and the Commission. Article 4, in turn, strengthened the standing of the court by stating that it should be considered equal to the other major institutions of the Community. ${ }^{79}$

All this set the new European Court of Justice quite apart from the ECSC-CJ. A new sort of Community court had been created - one that would influence dispute settlement institutions in many other RIOs in the coming decades.

\section{North American Free Trade Agreement}

We consider here the highly used dispute settlement mechanism ${ }^{80}$ for foreign investments laid out in Chapter 11 of NAFTA. Rather than a permanent court or other institutionalized body, Chapter 11 specifies guidelines for hoc tribunals capable of issuing binding decisions related to discrimination, uncompensated expropriation, and treatment inconsistent with international law by member states vis-à-vis foreign investors. In terms of scripts, Chapter 11 owed little to any other RIO and was 'revolutionary' or at the very least quite innovative in several respects. ${ }^{81}$ Yet, other RIOs certainly influenced the earlier stages of the process. As with the European Court of Justice, then, this case highlights how diffusion across RIOs can happen in the earlier phases of institutional design but be far less relevant in the final step, even in cases where the new RIOs supersede preexisting ones in the same spaces (and with the same membership).

What, then, prompted the problematization of investor rights among the NAFTA negotiators? Several factors played a role. Some were certainly endogenous to the region. North America as a whole during the 1980s had become a major destination of foreign direct investment, with flows among the three member states increasing in

\footnotetext{
77 Article 177; Martin Shapiro, 'The European Court of Justice', in Alberta M. Sbragia (ed.), EuroPolitics: Politics and Policymaking in the "New" European Community (Washington, DC: The Brookings Institution, 1992), p. 126.

78 Tamm, 'The History of the Court of Justice of the European Union since its Origin', pp. 19-20.

79 The Commission, Assembly (later Parliament), and Council.

80 For a list of cases, see http://www.international.gc.ca/trade-agreements-accordscommerciaux/topics-domaines/disp-diff/nafta.aspx (accessed on 5 September 2015).

81 Patrick Dumberry, 'The NAFTA Investment Dispute Settlement Mechanism: A Review of the Latest Case-Law', The Journal of World Investment, 2:1 (2001), p. 151; Kristin L. Oelstrom, 'A Treaty for the Future: The Dispute Settlement Mechanisms of the NAFTA', Law and Policy in International Business, 25 (1993), p. 799.
} 
every direction (except for Canadian investments into Mexico). ${ }^{82}$ The United States was accordingly interested in more secure access to Mexico.

But exogenous factors also played a role. Some of these were not RIOs. The United States was already a participant in numerous bilateral investment treaties, ${ }^{83}$ and these as a rule had for a long time guaranteed various sorts of investor protections. ${ }^{84}$ During the GATT Uruguay Round of 1986, in turn, the regulation of foreign investment disputes was entertained for the first time. ${ }^{85}$ Relevant were also frameworks from the International Centre for the Settlement of Investment Disputes Convention and the United Nations Commission on International Trade Law Arbitration Rules from the 1960s and 1970s, which appear in Chapter 11 as options for settlement procedures. All these informed American interest in particular in this topic.

But RIOs also influenced the problematization of investor rights in NAFTA. In general terms, NAFTA was the North American response to regional integration in Europe and elsewhere, and the corresponding perceived need for a far-reaching trade agreement supported by an enforceable regulatory framework. This applied to the movement of capital as well, especially for the United States and Mexico. Cameron and Tomlin describe for instance how Mexican President Carlos Salinas, upon returning from a trip to Europe in 1990, realized that 'Mexico could not count on its creditors for economic aid [and that] it would have to seek capital from foreign investors' ${ }^{86}$ Indeed, 'the shift in the global economy toward gigantic regional economic blocks, such as the creation of a common market in Europe, left Mexico with few choices. ... Remaining closed was not an option, and unilateral liberalization seemed to have few benefits'. ${ }^{87}$ The choice was therefore 'negotiated liberalization' in North America. Broadly speaking, then, the European experience mattered. In more specific terms, the presence of two RIOs with dispute settlement institutions - more importantly the Canada-United States Free Trade Agreement (CUSFTA) with its investor protection clauses ${ }^{88}$ and, probably to some extent, the 1987 ASEAN Agreement for the Promotion and Protection of

\footnotetext{
82 Alan M. Rugman and Michael Gestrin, 'NAFTA's Treatment of Foreign Investment', in Alan M. Rugman (ed.), Foreign Investment and NAFTA (Columbia, SC: University of South Carolina Press, 1994), pp. 48-50.

${ }^{83}$ Ray Jones, 'NAFTA Chapter 11 Investor-to-State Dispute Resolution: A Shield to Be Embraced or a Sword to Be Feared?', Brigham Young University Law Review, 22:2 (2002), pp. 527-59.

84 Barton Legum, 'The Innovation of Investor-State Arbitration under NAFTA', Harvard International Law Journal, 43:2 (2002), pp. 531-39.

85 Norris C. Clement et al., North American Economic Integration: Theory and Practice (Cheltenham, UK: Edward Elgar Publishing, 1999).

${ }^{86}$ Maxwell A. Cameron and Brian W. Tomlin, The Making of NAFTA: How the Deal Was Done (Ithaca and London: Cornell University Press, 2000), p. 1. 
Investments, with its binding arbitration tribunal - virtually ensured that the topic would be an issue at least for debate in the NAFTA context. 89

CUSFTA in particular influenced the framing phase. It offered one way of categorizing the problem (the liberalization of capital movement cannot occur if investors worry about the safety of their international investments) and offered a possible solution (investor rights should be therefore protected thought not if it means loss of national sovereignty). Hence 'Canada wanted to keep Chapter 11 as close to CUSFTA provisions as possible. Early bracketed texts were dominated by Canadian exceptions and limiting clarifications'. ${ }^{90}$ CUFSTA had also granted governments the right to review certain types of foreign investments - something also of importance to Canada. ${ }^{91}$ With CUFSTA's basic approach already shaping NAFTA's dispute settlement mechanism for anti-dumping and countervailing duty cases, ${ }^{92}$ its potential applicability to investments was clear.

At the same time, the US was 'interested in expanding even beyond the measures included in its maximalist bilateral agreements, and insisted from the beginning on starting from scratch, rather than building on CUSFTA. The United States was hoping to avoid such a provision in NAFTA' ${ }^{93}$ Hence, if only in a negative sense, CUFSTA helped define the American position as well. The United States' stance, we should note, was in a positive sense more in line with the principles found in a number of recent bilateral investment treaties, which themselves followed the principles of the International Centre for Settlement of Investment Disputes Convention, the Additional Facility Rules of the International Centre for Settlement of Investment Disputes Convention, and the United Nations Commission on International Trade Law Arbitration Rules. In the case of the United States and Canada, then, CUFSTA very much helped frame the issues and solutions on hand.

When it came to scripts, however, NAFTA planners departed significantly from the existing design of any RIO. As Olestrom put it, 'the dispute settlement provisions for investors form one section of the NAFTA that is not modeled on previous trade agreements'. ${ }^{94}$ The key characteristic of the dispute settlement mechanism on investments was something unprecedented for an RIO: it allowed investors to sue

\footnotetext{
${ }^{89}$ Jennifer A. Heindl, 'Toward a History of NAFTA's Chapter Eleven', Berkeley Journal of International Law, 24:2 (2006), p. 680. 
directly a country or sub-national jurisdiction. All past multinational trade agreements required investors to ask their states to sue on their behalf. ${ }^{95}$ This was the outcome the United States wanted given its fear of autocratic Mexican governmental actions over foreign investments - one that predictably caused considerable uproar over time among legal scholars and the public alike. In this regard, if there was diffusion, it was from bilateral investment treaties, which typically allowed for investor-state disputes. ${ }^{96} \mathrm{~A}$ second novel feature of NAFTA was the adoption of a 'negative list' of industries that would be exempt from the stated protection obligations (whereas past practice in CUSFTA and other RIOs required the listing of industries that were covered by those obligations ${ }^{97}$. A third and major innovation was the wide interpretation of investments as including 'minority interests, portfolio investment, and real estate property'. 98

The final design of NAFTA's dispute settlement mechanism in the investment area was thus remarkably innovative and standard-setting (Mercosur's 1994 Protocol of Colonia, for instance, would subscribe to the investor-state dispute concept). But these novelties do not mean that diffusion from other RIOs did not happen in the problematization and framing phases. There, the experiences of the EU and CUSFTA especially proved important.

\section{Southern African Development Community}

The Treaty of Windhoek transformed the Southern African Development Cooperation Conference into today's SADC with the goal of integrating the members' economies into an EU-type common market. Previously, it was a loosely structured organization built upon financial and technical support by international donors aimed at withstanding South Africa's apartheid destabilization policies vis-à-vis its neighbours through functional cooperation in selected policy areas. There was nothing 'natural' about the creation of a dispute settlement mechanism in the transformed SADC.

How did dispute settlement become problematized? Discussions on transforming the organization started in the region in the late 1980s. At this time, political debates initially problematized a variety of issues associated with the functioning of sectoral cooperation, and less so the institutional framework of the organization per se. For example, a virulent issue in the late 1980s was the selection criteria and approval procedure of projects that underwent changes due to the lack of coordination between

\footnotetext{
${ }^{95}$ Legum, 'The Innovation of Investor-State Arbitration under NAFTA'; Oelstrom, 'A Treaty for the Future', pp. 783-812.

96 Jones, 'NAFTA Chapter 11 Investor-to-State Dispute Resolution', p. 530.

${ }^{97}$ Gary Clyde Hufbauer and Jeffrey J. Schott, NAFTA Revisited: Achievements and Challenges (Washington, DC: Institute for International Economics, 2005), p. 202.

98 Hufbauer and Schott, NAFTA Revisited, p. 214.
} 
regional and national political priorities. ${ }^{99}$ In none of these debates was dispute settlement ever an issue, suggesting that there were no direct internal reasons for problematization. In fact, an expert team that had been tasked to make recommendations on a revised institutional structure for the organization in light of the envisaged transformation in its mandate noted that SADC's institutions 'are adequate and effective generally.' It presented a list of institutions to be officially included in a new Treaty, which did not contain a dispute settlement mechanism. ${ }^{100}$

Instead, problematization diffused from the outside. Even though the aforementioned expert group did mention that 'settlement of disputes shall be by arbitration'101, dispute settlement only rose to the agenda as a problem that required political action with the 1992 Consultative Conference, an annual meeting of SADC officials and representatives from external donors, which is widely seen as the most important event in the SADC's calendar of activities'.102 The theme document, which is used by donors to make financial pledges for the following period, engaged, for the first time, justifications for different approaches to economic integration in the region. Elaborated in cooperation with the most important donor agencies, including representatives from the $\mathrm{EU}$, it clearly stated that a regional development community 'requires mechanisms of mediation and arbitration'.103 The next Council of Ministers meeting then set the issue onto the political agenda. ${ }^{104}$ Nothing in the SADC context per se can explain this problematization. Instead, the documents for the 1992 conference suggest that problematization diffused from another RIO: the idea that economic integration requires mechanisms for dispute settlement came from the European experience, and was transferred by European experts who participated in the formulation of the theme document.

In this case, problematization was closely linked to framing. The first expert group initially framed the choice as one between an arbitration tribunal, which was a reform proposal being discussed in the General Agreement on Tariffs and Trade (GATT) at the time ${ }^{105}$, and a committee, which was the existing GATT mechanism. ${ }^{106}$ Yet after the

\footnotetext{
${ }_{99}$ Ibbo Mandaza and Arne Tostensen, Southern Africa: In Search of a Common Future. From the Conference to a Community (Gaborone: SADC Secretariat, 1994), pp. 38-39.

${ }^{100}$ SADCC Council of Ministers, Record of the Council of Ministers Held in Arusha, Tanzania on the 22nd and 23rd of August (1991), p. 379.

101 Ibid.

102 James Sidaway, "The (Geo)politics of Regional Integration: The Example of the Southern African Development Community', Environment and Planning D, 16:5 (1998), p. 564.

${ }^{103}$ SADCC, 'Towards Economic Integration', The Proceedings of the 1992 Annual Consultative Conference Held in Maputo, Mozambique, 29-31 January (1992), pp. 41-42.

${ }^{104}$ SADCC Council, August 1992, p. 35, emphasis added.

105 Manfred Elsig, and Jappe Eckardt, 'The Creation of the Multilateral Trade Court: Design and Experiential Learning', World Trade Review, 14:S1 (2015), p. S25.
} 
Secretariat had depicted the move towards economic integration as involving a choice between 'the proposed North American free trade zone or the European Economic Community'107, policy-makers started considering a wider range of frames for dispute settlement that also involved the more centralized form of arbitration of a standing court. All of these frames shared two key characteristics. They diffused from other international and regional organizations rather than constituting endogenous creations, and they categorized the problem of arbitration as one of choosing the right institutions with possible solutions requiring delegating competences to an independent body instead of a politically dominated process. At their first meeting after the consultative conference, the organization's Council of Ministers adopted this frame when noting that a regional Tribunal was to be among 'the central intergovernmental organs of the community'.108 It was eventually codified in the Windhoek Treaty (Art. 16), which provided for the establishment of a permanent Tribunal with compulsory jurisdiction and the power to 'give advisory opinions' over all matters of the treaty and subsidiary instruments. In accounting for the fact that policy-makers eventually chose a more institutionalized solution to the problem of arbitration, Lenz plausibly suggests that this was due to the fact that political leaders were eager to retain credibility with important international cooperation partners amidst rumours to withdraw funding from the organization after the end of the Cold War, among which the EU was the most important. ${ }^{109}$

The Tribunal's specific institutional features - its scripts - were to be laid down in a separate protocol, work on which started several years later. By that time, designing the Tribunal based on the template of the new dispute settlement system of the World Trade Organization, with which the Windhoek stipulations were fully compatible, appeared like the 'natural' choice for a group of countries that were largely unwilling to cede significant amounts of sovereignty. When signing the protocol in 2002, however, policy-makers showed 'a revealed preference to emulate the ECJ' due to three key institutional features of the Tribunal: a supranational Commission that monitors state compliance, a preliminary rulings mechanism that is a literal copy of Article 177 of the Treaty of Rome, and a system of administrative and constitutional review that provides

\footnotetext{
106 SADCC Council of Ministers, Record of the Council of Ministers Held in Arusha, Tanzania on the 22nd and 23rd of August (1991), p. 379.

107 SADC Council of Ministers, Record of the Council of Ministers, 28 August (1991), p. 361.

108 SADCC, 'Towards Economic Integration', p. 35.

109 Lenz, 'Spurred Emulation', pp. 165-66.
} 
for private access. ${ }^{110}$ As before, this choice was readily explicable by a mix of EUoriented epistemic communities that were involved in the Protocol's drafting, as well as an external context characterized by another legitimacy crisis with external donors, on which the organization continued to be highly dependent.111 In sum, the SADC Tribunal constitutes an instance of extensive diffusion, with all of the three decision-making steps leading to the final outcomes influenced by external models, above all the EU's.

\section{Conclusion: Theoretical implications and conditions of diffusion}

In this article, we have sought to refine our understanding of diffusion's causal influence on RIOs. Drawing on insights from public policy research and sociological work on organizations, we offered a conceptual framework that allows scholars to extend their focus beyond the final design (scripts, in our terminology) of policy and institutional outcomes. We suggested that policies and institutional arrangements in RIOs result from three distinct decision-making stages: problematization, framing, and scripting. Diffusion across RIOs can affect any combination of these three stages. Convergence thus need not be the only marker of diffusion: diffusion can happen also when we observe persistent variation in final design. We illustrated this conceptual logic with a structured comparison of the establishment of dispute settlement institutions in the EEC, NAFTA, and SADC. In this section, we discuss three theoretical implications of our analysis and propose two general conditions under which diffusion is likely to affect the three stages of decision-making in RIOs.

As to theoretical implications, the findings suggest, first, a reconsideration of the nature of diffusion as a causal force. Much of the literature, not only on RIOs but beyond, depicts diffusion as a force for convergence in final designs. ${ }^{112}$ From this perspective, diffusion accounts are generally seen as posing a theoretical challenge to functional theories of institutional design and public policymaking. Our analysis indicates that this view is overly narrow. Especially of diffusion triggers the recognition of a situation as a problem that requires political action (problematization) and shapes the way in which the problem is understood (framing), it provides a strong impetus for departing from the status quo, independent of the resulting final outcome - thus, it constitutes a force for change. If this argument is correct, diffusion accounts challenge a potentially much

\footnotetext{
110 Alter, 'The Global Spread of European Style International Courts', p. 145; see also Alter, The New Terrain of International Law.

111 See Lenz, 'Spurred Emulation', pp. 166-67.

112 For a crique of this view in sociology, see Beckert, 'Institutional Isomorphism Revisited'; Elkins and Simmons, 'On Waves, Clusters, and Diffusion', p. 36.
} 
larger class of theoretical approaches including, above all, certain variants of neoinstitutionalist theories that predict organizational stability. Historical institutionalism, in particular, has identified powerful forces - sunk costs, adaptive expectations, learning and coordination effects, and resistance by the beneficiaries of the status quo - that reinforce the continuity of institutional arrangements. ${ }^{113}$ Similarly, a large sociological literature contends that institutions rest on shared normative routines and commitments that have a tendency to be chronically reproduced. This has led to a widespread assumption, present also among International Relations scholars, that international organizations 'are notoriously resistant to reform or redirection'.114 Our analysis suggests that diffusion dynamics might undermine the endogenous selfreinforcement dynamics characteristic of path dependent processes. In this sense, diffusion pressures act effectively as an external shock on the receiving organization and their role is thus consistent with the thinking of some neo-institutionalists who see external shocks as the primary causes of disruption triggering organizational change. The specific ways in which diffusion does so invites further research.

Second, our framework contributes to the debate among scholars on 'whether or not diffusion implies the adoption of some variant of the original model.'115 There is a growing view, resisted by some, that even non-adoption might indicate diffusion to the extent that a particular model is considered for adoption, even if it is ultimately rejected.116 The claim has merit, and the two positions appear contending because they in fact focus on different stages of decision-making: whereas the mainstream view non-adoption indicates non-diffusion - recognizes diffusion only in final designs, the other position essentially acknowledges, as do we, that diffusion might operate at earlier stages of decision-making. When a model is considered for adoption and ultimately rejected as a template for final design, it might nevertheless subtly shape the way an existing arrangement is problematized, or it might frame, in a generic fashion, the problem and potential solutions. In this sense, even non-adoption of the institutional template can indicate a causal role for diffusion. The NAFTA case offers an example.

A third theoretical implication concerns the interaction between diffusion pressures and domestic politics in shaping outcomes. Diffusion studies are often set against explanations emphasizing internal factors in general and domestic politics in particular. The common conceptualization of diffusion as concerning final design is at

\footnotetext{
113 Kathleen Thelen, 'Historical Institutionalism in Comparative Politics', Annual Review of Political Science, 2 (1999), pp. 369-404; Pierson, Politics in Time.

114 Barnett and Finnemore, Rules for the World, p. 2.

115 Solingen and Börzel, 'Introduction', p. 9.

116 For example Risse, 'The Diffusion of Regionalism', pp. 5-6.
} 
the root of this disagreement. It has led scholars to treat the two sets of factors as theoretical anti-theses: if a decision to adopt a particular policy or institution can be explained as the result of diffusion it cannot be explained by domestic politics and vice versa. Our framework offers an alternative perspective. By distinguishing discrete stages in decision-making processes, we open up analytical space for both diffusion and domestic politics to matter in a sequential fashion. We gave some illustrations of this when introducing our conceptual framework; our three empirical illustrations, more systematically, displayed different sequences of the key 'dynamics of "imitation and innovation" through which transnational models are instantiated in national settings.'117 We hence recognize conceptually, not just empirically, that diffusion and domestic politics do not constitute anti-theses, and provide one coherent way for conceptualizing their interaction.

This helps to shed new light on the localization debate. Localization scholars recognize diffusion as a salient influence on local processes but highlight processes of translation and adaptation of foreign norms, ideas, and models by local actors. Convergence, these scholars contend, is hardly ever an outcome under such circumstances, and local actors should enjoy analytical primacy.118 Our framework suggests that these arguments tend to be based on the misguided dichotomy that an outcome is affected primarily either by domestic politics or by diffusion. These scholars actually recognize that, in our terminology, it need not be final designs but can also be problems or frames that diffuse from abroad. While domestic politics might be the major determinant of scripting, as these scholars contend, diffusion can nevertheless shape problematization or framing - as was the case in the EEC and NAFTA. Thus, this controversy appears overblown if we recognize conceptually that domestic politics and diffusion can affect different stages in decision-making.

We end by reflecting on one final question: Under what conditions is diffusion likely to influence RIO decision-making? The above empirical illustrations, as well as other diffusion research, suggest two general conditions. First, we expect network ties to play an important role. The closer such network ties, the more likely is diffusion going to be. Two types of network ties are relevant here. One is overlap in membership. The higher the membership overlap between two RIOs, the more likely will diffusion affect

\footnotetext{
117 Marc Schneiberg and Elisabeth Clemens, 'The Typical Tools for the Job: Research Strategies in Institutional Analysis', Sociological Theory, 24:3 (2006), p. 200.

118 See fn. 3 and 11.
} 
decision-making because relevant information flows are likely to occur. ${ }^{119}$ This is what we saw in the EEC and NAFTA cases, where shared membership across two legally distinct RIOs was a powerful facilitator of diffusion. These two cases also suggest that such membership overlap is most likely to affect the framing stage, and maybe also problematization. It appears to leave more room for innovation at the scripting stage. Another relevant network tie, especially visible in the SADC case, is interaction with a powerful organizational pioneer. The EU is generally seen as the most successful example of regional integration, and it actively supports such processes in other organizations. ${ }^{120}$ Close ties with the pioneer appear to increase the likelihood if diffusion across stages of decision-making. Whether this influence lessens as we move from problematization to scripting remains to be analyzed. The absence of such close ties, in turn, might explain why NAFTA appeared less influenced by the EU model of dispute settlement.

While network ties are relational and therefore tend to be actor-oriented, diffusion is also facilitated by broader structural conditions. A second condition, then, is that the total amount of RIOs in which problems, frames, or scripts have diffused affects the likelihood of diffusion to other RIOs. In an analogy to Strang's influential definition of diffusion ${ }^{121}$, we might hypothesize that the prior adoption of a problem, frame, or script in a population alters the probability of adoption of remaining non-adopters. Concerning dispute settlement, we would thus expect that the more RIOs problematize the issue in their organization, the higher the likelihood that other RIOs will follow suit. The same hypotheses can be rendered for frames and scripts. Once a certain threshold level of adopters is reached at each stage, a specific problem, frame, or script assumes a takenfor-granted character, and is therefore likely to diffuse more rapidly. ${ }^{122}$ Over time, then, variation in problematization, framing, and scripting within the population is likely to diminish - a hypothesis well known from world polity theory. ${ }^{123}$ What our framework adds to this idea is that this structuration process follows a sequential logic that evolves from problematization through framing towards scripting. In other words, we are likely

\footnotetext{
119 Hyeran Jo and Hyun Namgung, 'Dispute Settlement Mechanisms in Preferential Trade Agreements: Democracy, Boilerplates, and the Multilateral Trade Regime', Journal of Conflict Resolution, 56:6 (2012), pp. 1041-68.

120 Lenz, 'EU Normative Power and Regionalism'.

${ }^{121}$ David Strang, 'Adding Social Structure to Diffusion Models', Sociological Methods and Research, 19:3 (1991), p. 325.

122 This is an important element of Finnemore and Sikkink's norm cycle. See Martha Finnemore and Kathryn Sikkink, 'International Norm Dynamics and Political Change', International Organization 52:4 (1998), pp. 887-917.

123 DiMaggio and Powell, 'The Iron Cage Revisited', p. 156.
} 
to see structuration tendencies first in problematiztion, then in framing, and finally in scripting.

This sequential macro-hypothesis appears to be consistent with the general evolution of dispute settlement in RIOs and preferential trade agreements (PTAs) that is the subject of much recent analysis. The relevant literature indicates that some form of institutionalized dispute settlement in RIOs and PTAs is becoming increasingly common, which implies, in turn, that RIOs and PTAs without any such mechanism have become rare. ${ }^{124}$ This suggests that the issue of dispute settlement is problematized almost 'automatically' when such agreements are being negotiated. In other words, variation across RIOs and PTAs appears to have decreased enormously in problematization. Yet increasing similarity goes further. Beyond problematization, most RIOs and PTAs nowadays feature dispute settlement mechanisms that involve independent third parties as adjudicators, implying that dispute settlement is increasingly framed as a problem that requires independent adjudication. Nevertheless, in terms of scripting much variation appears to remain. It is at this stage of decision-making that diffusion is potentially the least widespread, partly because no single uncontested model of how to address dispute settlement design has emerged. Clearly articulating and rigorously testing such hypotheses across stages of decision-making remains a fruitful area for future research.

${ }^{124}$ Karen Alter and Liesbet Hooghe, 'Regional Dispute Settlement', in Tanja Börzel and Thomas Risse (eds), Oxford Handbook of Comparative Regionalism (Oxford: Oxford University Press, forthcoming); Smith, 'The Politics of Dispute Settlement Design'. 